\title{
PERANCANGAN TURBIN AIR TIPE ALIRAN SILANG DENGAN VARIASI 3 KECEPATAN POMPA
}

\author{
${ }^{(1)}$ Abdurahim Sidiq, ${ }^{(2)}$ Akhmad Gazali \\ (1)Teknik Mesin(2)Teknik Sipil, Fakultas Teknik, Universitas Islam Kalimantan MAB \\ Jl. Adhiyaksa No. 2 Kayu Tangi, Banjarmasin \\ Email : rahimsidiqs7q@gmail.com
}

\begin{abstract}
Abstrak
Turbin air adalah alat yang merubah energi aliran menjadi energi mekanik poros. Pemilihan jenis turbin yang sesuai untuk suatu pembangkit tenaga mikro hidro tergantung pada karakteristik aliran yaitu tinggi jatuh dan debit aliran yang tersedia serta kecepatan turbin. Mikrohidro merupakan pembangkit listrik yang mudah diterapkan pada masyarakat karena pembuatannya mudah, peralatan yang digunakan sederhana dan tempat yang digunakan relatif lebih kecil.Metode yang digunakan dalam penelitian ini adalah metode kuantitatif yaitu melakukan perhitungan untuk mengetahui seberapa besar daya generator yang dihasilkan dari 3 variasi kecepatan pompa (1200 rpm, 1800 rpm, dan $2300 \mathrm{rpm}$ ).Untuk turbin air tipe aliran silang didapatkan data tertinggi putaran pada turbin yaitu 207,9 rpm dan daya terbesar yang dihasilkan oleh generator 21,8 watt pada kecepatan putaran pompa tertinggi yaitu $2300 \mathrm{rpm}$.
\end{abstract}

Kata kunci : Turbin air, Alternator, Daya, aliran silang, Generator

\begin{abstract}
A water turbine is a device that converts flow energy into shaft mechanical energy. The choice of turbine type that is suitable for a micro hydro power plant depends on the flow characteristics ie the height of the fall and the available flow rate and the turbine speed. Micro hydro is a power plant that is easily applied to the community because it is made easy, the equipment used is simple and the place used is relatively smaller. The method used in this study is a quantitative method that is doing calculations to find out how much generator power is generated from 3 variations of pump speed (1200 rpm, 1800 rpm, and $2300 \mathrm{rpm}$ ). For the cross flow type water turbine the highest rotation data is obtained on the turbine which is 207.9 rpm and the biggest power generated by the generator 21.8 watts at the highest pump rotation speed is $2300 \mathrm{rpm}$.
\end{abstract}

Keywords: Water turbine, Alternator, Power, cross flow, Generator

\section{PENDAHULUAN}

Energi listrik merupakan energi yang mempunyai peranan penting bagi masyarakat. Salah satu manfaatnya adalah untuk penerangan. Keadaan kelistrikan di Indonesia sekarang ini sangat memprihatinkan apalagi sumber migas yang terdapat di bumi sangat terbatas, dan pada suatu saat akan habis. 
Oleh karena itu berbagai penelitian dilakukan untuk menemukan sumber energi di luar migas, sebagai sumber energi alternatif yang dapat dimanfaatkan sesuai dengan kebutuhan. Salah satu sumber energi alternatif yang dapat dikembangkan adalah Turbin air.

Turbin air adalah alat yang merubah energi aliran menjadi energi mekanik poros. Pemilihan jenis turbin yang sesuai untuk suatu pembangkit tenaga mikro hidro tergantung pada karakteristik aliran yaitu tinggi jatuh dan debit aliran yang tersedia serta kecepatan turbin.

\section{METODE PENELITIAN}

Metode yang digunakan dalam penelitian ini adalah eksperimen metode kuantitatif yaitu melakukan perhitungan untuk mengetahui seberapa besar kecepatan putaran turbin air aliran silang dan juga daya yang dihasilkan oleh alternator dengan 3 kali percobaan kecepatan :

1. Menggunakan Avometer untuk mengukur tegangan dan arus yang dihasilkan dalam 3 kali percobaan kecepatan.

2. Menggunakan Tachometer kecepatan putaran poros turbin.

\section{Desain Perancangan Turbin Air Tipe Aliran Silang}

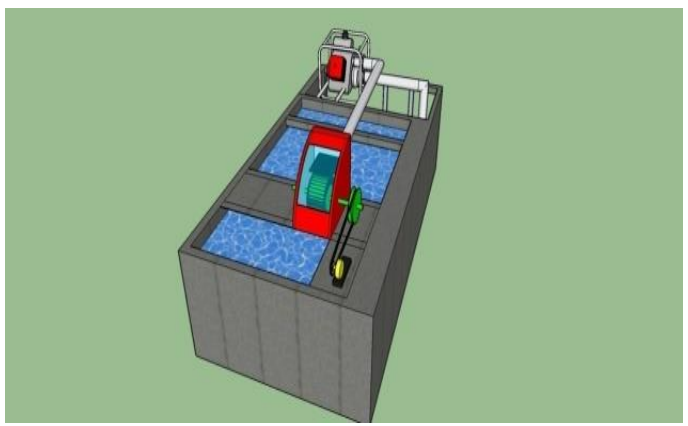

Gambar 3.1 Turbin Air tipe aliran silang bagian depan

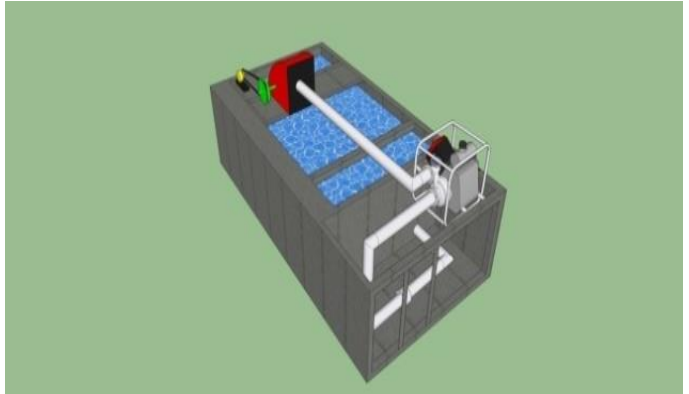

Gambar 3.2 Turbin Air tipe aliran silang bagian belakang

\section{HASIL DAN PEMBAHASAN \\ Melakukan Pengujian}

Melakukan percobaan pada putaran mesin pompa dari kecepatan rendah(1200 Rpm), sedang(1800 Rpm), dan tinggi(2300 Rpm). Untuk mengetahui kecepatan putaran turbin (menggunakan tachometer) serta daya yang dihasilkan generator dari 3 kecepatan mesin pompa tersebut.

Menggunakan

Rumus : P = V.I

Dimana P : Daya (Watt)

$\mathrm{V}$ : Tegangan (Volt)

I : Arus (Ampere)

Tabel 4.1. $1200 \mathrm{Rpm}$ mesin

\begin{tabular}{|l|l|l|l|l|}
\hline NO & $\begin{array}{l}\text { Putaran } \\
\text { Turbin } \\
(\text { Rpm) }\end{array}$ & $\begin{array}{l}\text { Tegangan } \\
\text { (Volt) }\end{array}$ & $\begin{array}{l}\text { Arus } \\
\text { (Ampere) }\end{array}$ & $\begin{array}{l}\text { Daya } \\
\text { (Watt) }\end{array}$ \\
\hline 1 & 107,7 & 7,9 & 0,38 & 3 \\
\hline 2 & 105,8 & 7,5 & 0,36 & 2,7 \\
\hline 3 & 109,3 & 7,6 & 0,39 & 2,9 \\
\hline 4 & 110,5 & 7,9 & 0,42 & 3,3 \\
\hline 5 & 114 & 8,1 & 0,45 & 3,6 \\
\hline $\begin{array}{l}\text { Rata } \\
\text {-rata }\end{array}$ & 109,5 & 7,8 & 0,4 & 3,1 \\
\hline
\end{tabular}




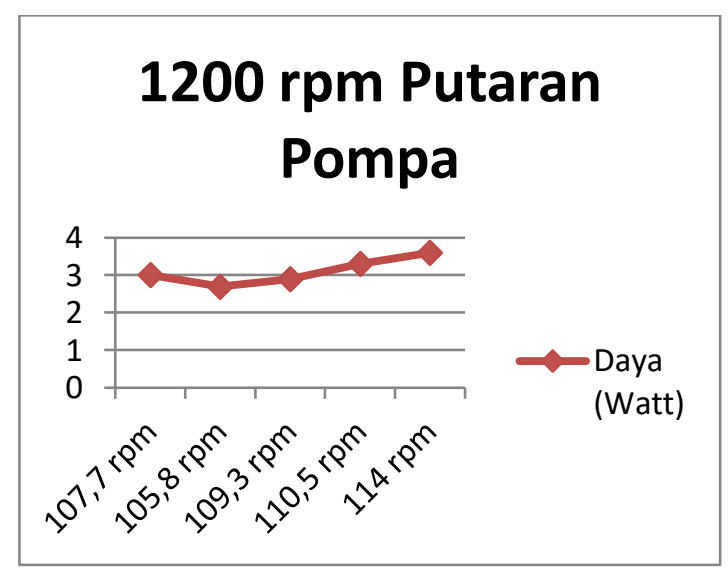

Grafik 1200 rpm

Tabel 4.2 Data 1800 RPM Mesin

\begin{tabular}{|l|l|l|l|l|}
\hline NO & $\begin{array}{l}\text { Putar } \\
\text { an } \\
\text { Turbi } \\
\text { n } \\
\text { (Rpm } \\
\text { ) }\end{array}$ & $\begin{array}{l}\text { Tegang } \\
\text { an } \\
\text { (Volt) }\end{array}$ & $\begin{array}{l}\text { Arus } \\
\text { (Ampe } \\
\text { re) }\end{array}$ & $\begin{array}{l}\text { Day } \\
\text { a } \\
\text { (Wat } \\
\text { t) }\end{array}$ \\
\hline 1 & 174,4 & 12,9 & 0,48 & 6 \\
\hline 2 & 173,2 & 12,6 & 0,44 & 5,5 \\
\hline 3 & 172,2 & 12,8 & 0,50 & 6,4 \\
\hline 4 & 174,6 & 13 & 0,52 & 6,7 \\
\hline 5 & 175.1 & 12,9 & 0,63 & 8,1 \\
\hline
\end{tabular}

\begin{tabular}{|c|c|c|c|c|}
\hline No & \multicolumn{2}{|c|}{$\begin{array}{l}\text { Kecepatan } \\
\text { Pompa } \\
(\mathrm{rpm})\end{array}$} & $\begin{array}{l}\text { Putaran } \\
\text { Turbin } \\
(\mathrm{rpm})\end{array}$ & $\begin{array}{l}\text { Daya } \\
\text { (Watt) }\end{array}$ \\
\hline 1 & 1200 & & 114 & 3,6 \\
\hline 2 & 1800 & & 175,1 & 8,1 \\
\hline 3 & 2300 & & 207,9 & 21,8 \\
\hline $\begin{array}{l}\text { Rat } \\
\text { a- } \\
\text { rata }\end{array}$ & $\begin{array}{l}173,9 \\
-\end{array}$ & 12,8 & 0,51 & 6,5 \\
\hline
\end{tabular}

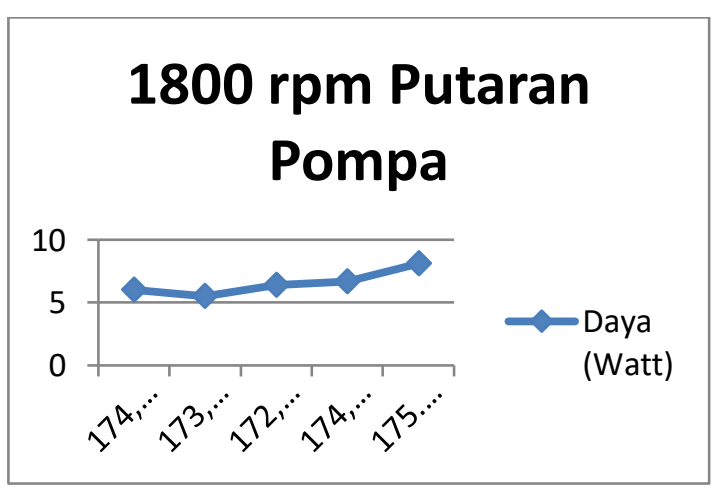

Grafik 1800 rpm

Tabel 4.3 Data 2300 RPM Mesin

\begin{tabular}{|l|l|l|l|l|}
\hline NO & $\begin{array}{l}\text { Putaran } \\
\text { Turbin } \\
(\text { Rpm })\end{array}$ & $\begin{array}{l}\text { Tegangan } \\
\text { (Volt) }\end{array}$ & $\begin{array}{l}\text { Arus } \\
\text { (Ampere) }\end{array}$ & $\begin{array}{l}\text { Daya } \\
\text { (Watt) }\end{array}$ \\
\hline 1 & 204,8 & 14,3 & 1,32 & 15,6 \\
\hline 2 & 207,9 & 14,5 & 1,53 & 16 \\
\hline 3 & 206,6 & 14,4 & 1,29 & 18,5 \\
\hline 4 & 206,1 & 14,3 & 1,39 & 19,8 \\
\hline 5 & 206,9 & 14,4 & 1,52 & 21,8 \\
\hline $\begin{array}{l}\text { Rata- } \\
\text { rata }\end{array}$ & 206,4 & 14,4 & 1,41 & 18,3 \\
\hline
\end{tabular}

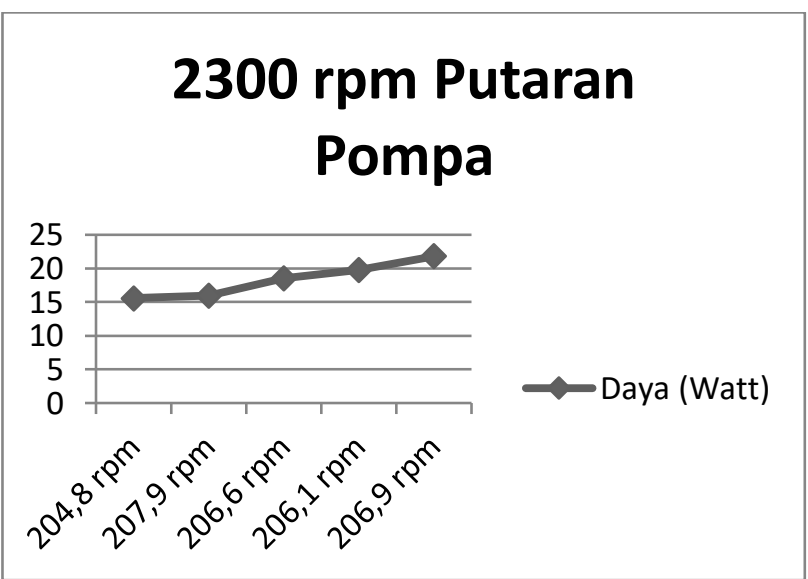

Grafik 2300 rpm

Dari hasil data tabel penelitian diatas dapat disimpulkan seberapa besar kecepatan Putaran turbin dan seberapa besar daya yang dihasilkan generator setelah melakukan 5 kali pengujian.

\section{KESIMPULAN}

Dari data yang didapat setelah melakukan pengujian dapat disimpulkan:

1. Pada kecepatan putaran rendah 1200 rpm pada mesin pompa diperoleh kecepatan putaran turbin terbesar adalah $114 \mathrm{rpm}$ dan daya keluaran terbesar yang dihasilkan oleh generator ialah 3,6 watt.

2. Pada kecepatan putaran sedang 1800 rpm pada mesin pompa diperoleh kecepatan putaran terbesar adalah 175,1 rpm dan daya keluaran 
terbesar yang dihasilkan oleh generator ialah 8,1 watt.

3. Pada kecepatan putaran tinggi 2300 rpm pada mesin pompa diperoleh kecepatan putaran terbesar 207,9 rpm dan daya keluaran terbesar yang dihasilkan oleh generator ialah 21,8 watt

\section{REFERENSI}

[1] http://www.satuenergi.com/2015/04/ jenis-jenis-turbin-air-pltapltmh.html

[2] http://eprints.ums.ac.id/23990/2/4. BAB_I.pdf

[3] https://kedairastavara.wordpress.co $\mathrm{m} / 2012 / 07 / 27 /$ pengertian-dankomponen-komponen-alternator/

[4] Mafruddin, M., Irawan, D., 2017. Pembuatan Turbin Mikrohidro Tipe Cross-Flow Sebagai Pembangkit Listrik Di Desa Bumi Nabung Timur. Turbo J. Progr. Stud. Tek. Mesin 3, 7-12. https://doi.org/10.24127/trb.v3i2.12

[5] Setiawan, Y., Wahyudi, I., Nandes, E., 2017. Unjuk Kerja Turbin Air Tipe Cross Flow Dengan Variasi Debit Air Dan Sudut Serang Nosel. Turbo J. Progr. Stud. Tek. Mesin 2, 21-25. https://doi.org/10.24127/trb.v2i1.3

[6] Studi, P., Mesin, T., Islam, U., Mab, K., 2016. MIKROHIDRO Abdurahim Sidiq 02, 49-51.

[7] Studi, P., Mesin, T., Teknik, F., Buana, U.M., 2014. PERANCANGAN MODEL AIR ALIRAN SILANG ( CROSS FLOW TURBINE ) DENGAN HEAD 2 m DAN DEBIT $0,03 \mathrm{~m} 3$ / s 03, 7-12.

[8] Suyanto, M., Widyastuti, N., Elektro, J.T., Informatika, J.T., Industri, F.T., Sains, I., Yogyakarta, T.A., n.d. PEMANFAATAN ALTERNATOR DC DENGAN INVERTER PADA ( PLTMh ) SEBAGAI PENYEDIA DAYA LISTRIK PRODUKTIF DI. 